Research.

\title{
THE EFFECT OF VOLUNTARY DISCLOSURE UPON THE EARNINGS RESPONSE COEFFICIENT
}

\author{
Ridla Tsamrotul Fuady \\ Lecturer at STIE Binaniaga, Bogor
}

\begin{abstract}
This research aims to examine the effect of voluntary disclosure by calculating the unexpected earnings and being measured thru the voluntary disclosure index upon the earning response coefficient measured by cumulative abnormal return and leverage, price to book value and the size of a company which is controlled variable. This research has been covering all the emitents on the Syariah Share Index which is the Jakarta Islamic Index (JII) registered at the Indonesia Stock Exchange (BEI) in 2014. The indicator of the voluntary disclosure has adopted the index of Global Reporting Initiative (GRI) G4 version (the newest) refers to 3 (three) selected main components which is the Economic performance, social and environment performance.

Data collection method has applied a documentation study which is by studying the evident, scientific paper, article, journal and website relating to the research objects.

The result of the research has indicated that an empiric study can not describe the effects of the voluntary disclosure upon the earning response coefficient (ERC). The same conclusion has been obtained regarding each kind of voluntary disclosure which is the voluntary disclosure related to the financial information and the voluntary disclosure related to the social and environment information.
\end{abstract}

Keywords : Voluntary disclosure, earnings response coefficient, Jakarta Islamic Index.

\section{INTRODUCTION}

In line with a business development recently, the emitents competition to attract the intention of the investors in the stockmarket have obliged the companies to perform the disclosure of their information at least the same with their former competitor's disclosure. The extent of the information disclosure has attracted the intention of the consumers accordingly to establish the optimum public image (Kartadjumena, 2010) within Widyaningsih (2013). Therefore, the company has obtained a benefit providing such the voluntary disclosure which is being able to reduce the asymmetric information occured as well as to reduce the external cost of the company obviously. Voluntary disclosure is believed could increase the shares liquidity, reduce the capital cost, and increase the information needed by the agent in the stockmarket (Ludovicus, 2005) within Widiyaningsih (2013).

The voluntary disclosure can be categorized into two categories, the tradional voluntary disclosure refers to the information related to the economic performance of a company, operational activities decisions, costs and the company's investment; non-traditional voluntary disclosure refers to the information provided relating to the interaction of the company with either physics or social environment. The disclosure relating to the interaction of social and environment has been the big issue. The environmental issue is believed could create a negative impact of the environment and the community surroundings. The company has been obliged to perform the Corporate Social Responsibility (CSR). CSR has Triple Bottom Line concepts which is the profit, the people and the planet that is in compliance with the concept described by Elkington (1997) in Fuady (2013). The government has requested the companies to implement the CSR

Ridla Tsamrotul Fuady: The Effect of Voluntary Disclosure upon

The Earnings Response Coefficient 
according to the Limited Companies Regulation No. 40 year of 2007 regarding the obligation of the companies dealing with the nature resources to apply the Corporate Social Responsibilities obviously.

An additional information that has been declared by the company either the financial information or non financial information has been improving the value of the company to the investor. The investors has a limited information about the company profit and sometimes it is biased. The Informativeness of earnings will become bigger when the uncertainty of the companies for the future has happened. (Sayekti, 2007) within Pradipta and Purwaningsih (2011). The informativeness of earnings has been measured by applying Earning Response Coefficient (ERC). On the other hand, the more uncertainty of the prospect of the company occurs in the future, the bigger ERC happens. The company has disclosed an additional information refers to social and environment responsibility in the yearly report in order to reduce the uncertainty matter. It explains that the disclosure of the social and environment responsibility can reduce the ERC of the company. More information of the social and environment responsibilities have been announced, it has made the investor not only focusing to the profit of the company to invest.

Iswardani (2012) conducted an empirical study about the coverage of voluntary disclosure upon the ERC to figure out the correlation between the profit and the shares earnings. The research has indicated that the voluntary disclosure and the profit altogether have affected the shares earnings. It explains that the voluntary disclosure has been affecting the ERC positively. Furthermore, the research of Widiastuti (2002) within Fitriana (2011), by examining the effect of a voluntary disclosure in the yearly report, it has affected the ERC negatively. But, according to the research of Widyaningsing (2013) examined the effect of a voluntary disclosure upon the ERC indicating that the financial information, social information and the environment information has not affected the ERC.

The previous research has concluded a varied conclusion since it has not differentiated yet the mandatory disclosure component and the voluntary disclosure component, so that, the contribution of the actual voluntary disclosure has not yet been discovered.

Moreover, none of any research has been studying the effect of the voluntary disclosure upon the earning responses coefficient at Syariah stock market registered at BEI (Indonesia Stock Exchange). The Syariah investment in Indonesia is identical to Jakarta Islamic Index (JII). The shares registered at JII are the most liquid shares having a big marketable capitalization. The previous research had not applied yet the indicator of a voluntary disclosure which is the global reporting index (GRI) G4 version published mid of 2013 describing and classifying the details of the component of each disclosure. GRI G4 are focusing more upon the company's needs regarding the reporting process and the final report consisting of the material business topics issues and the stakeholders' requirements accordingly. Focusing to this business material will issue more relevant report, more credible and user friendly obviously. At the end, the company could provide better information about the continual problems to the market and people.

Therefore, the research being done is to examine the effects of voluntary disclosure upon the earning reponses coefficient at the companies which their shares have been registered at Jakarta Islamic Index (JII) in 2014.

\section{LIBRARY REVIEW}

\section{The Theory Related to Voluntary Disclosure}

\section{Legitimate Theory}

This theory has described the company will always try to ensure that the value of the company has been in compliance with the applicable value at the community 
surroundings. The consequency upon this theory is that the company is obliged to execute it obviously in order to meet the expectation of the community either explicitly or implicitly. On the other hand, the people will allow the company to utilize the avalaible resources and to operate it at the community area. When the company can not be able to cover the expectation of the people, it will jeopardize the people trust and the company should have to do more efforts to regain their trust. The voluntary disclosure of a company is an effort to provide the information to the people why the company has not been able yet meeting the people expectation and the company has been providing the solution to solve the problems.

\section{Stakeholder Theory}

Stakeholder is either internal or external party refers to government, competitors, society surroundings, international environment, external institutions (NGO, etc.), the environmental observation institutions, the employees of the company, minority people, etc which is their existency has been affecting the company and the company has been affecting them as well. The company can not ignore the surroundings social setting. The company has to be fully aware of the stakeholders legitimacy and to include them in relation with the company policy design and decision making, so that the achievement of the company's goal will happen which is the stability of the company and the guarantee of going concern.

\section{Signaling Theory}

The voluntary information disclosure of a company is an applicable signal for the market. When a company has disclosed the information less than other companies, market will consider it as 'bad news signal'.

\section{Political Theory}

The voluntary disclosure done by a company is an effort to reduce political cost. Political cost is an additional expense occurred due to the wellbeing transfer such as, high taxes, high cost of financial reporting as well as high losses refers to the unefficiency of the operational of the company accordingly. The voluntary disclosure relating to the political cost has been affected by two factors which is the company itself and the type of the industry.

\section{The Economics Consequency}

The economics consequency of the voluntary disclosure of a company upon the stockmarket (Lodovicus, 2005) within Widyaningsih (2013):

1. Increasing the shares liquidity.

Diamond and Verrechia (1991), Kim and Verrechia (1990) within Widiyaningsih (2013) describing that the voluntary disclosure has been reducing the asymmetric information among the investors. The company having a high disclosure value has ensured the investors that the shares transaction has happened normally reflecting to the increasing of company's share liquidity. Some researches who have been supporting this determination are as follows; Welker (1995) in Widiyaningsih (2013) indicated a significant negative correlation between the financial report of the company's disclosure level and its bid-ask spreads. Healy, et. al. (1999) in Widiyaningsih (2013) figured out that the company having an increasing analysis of the disclosure level has had a significant and high bid-ask spreads.

2. Reducing the capital cost.

Barry and Brown (1984, 1985, 1986) within Widiyaningsih (2013) determined that when a disclosure has not been completed perfectly, the investor has to take the risk refers to the forecasting of the investment payment. When this kind of risk can not be verified, the investor will request the incremental payment due to the risk of the information. As the result, a company having a high disclosure level but low risk will

Ridla Tsamrotul Fuady: The Effect of Voluntary Disclosure upon

The Earnings Response Coefficient 
have a lower capital cost comparing to the company having a low disclosure level but high risk of the information.

3. Improving the information.

Lang and Lundholm (1993) within Widiyaningsih (2013) figured out that the company having more the informative disclosure has supported the forecasting analysis more accurate and less revision to increase the demand of the analyst service.

\section{Corporate Social Responsibility}

Nurfajiyah (2011) determined that the Corporate Social Responsibility (CSR) is a company responsibility to provide the wellbeing of the people and to take care the environment accordingly refers to the triple bottom line.

According to Brodshaw and Vogel (1981) within Sukaharsono (2010) determined three dimensions of CSR coverage are as follows; a. Corporate philantrophy is a social activity done by an organization which is the social activities have not connected directly to the normal activity of the organization. b. Corporate responsibility is the social responsibility activites done by the organization to pursue the profit of the organization. $c$. Corporate policy is relating to the organization relationship with the government refers to the government policies affecting either the organization or the society overall.

Lako (2011), a basic argument of CSR deconstruction is the theory of corporate accountability. According to this theory, a company should have to be responsible for all the consequencies appearing directly of indirectly to all stakeholders. Some basics of the theory have had an equal perspective with the company accountability theory, which is; First, stakeholders theory describing that the success of a company is depending on the ability to equalize varied stakeholder's requirements as well as the society and the environment. Once the company has succeeded, it will gain a continuous support of the market development, selling, and profit. Second, theory of corporate sustainability determined that a company could be able to develop continuously when it has integrated the business goal, social and ecology goals accordingly. The business development has to be in accordance with the three pillars, economy, social and environment which will not jeopardize the future generation to live and to support their needs.

The aforementioned point of view has established the principles of triple bottom line accounting. This principle aims to declare and to integrate the information report about the environment, social and finance into one package of the report which is the triple bottom line reporting. In the perspective of triple bottom line accounting,hence, cost-benefit of the social and environment information can be quantified accordingly and the related materials can be reported in the accountancy report (triple bottom line reporting) and it will obtain the potential benefit of the economy in the future.

\section{The Earnings Response Coefficient}

The Earnings Response Coefficient (ERC) is a measurement regarding the abnormal turnover of the Shares responding to the unexpected earnings reported by the company that issued the related shares (Scott, 2003) within Widyaningsih (2013). ERC is a tool for the investor to perform a fundamental analysis which is the evaluation model to define a market response based on the profit information issued by the company. ERC is a coefficient obtained from the regression between shares value and accountancy profit. For example; a company is expected to report the profit of Rp 10,000.00/share but the company has declared the profit of the shares is Rp 15,000.00 (surprising positive profit or good news) refers to the increasing of $500 / 5000=0.1$ of the company's share obviously. 


\section{The Research Design}

This research aims to figure out whether the voluntary disclosure refers to the financial item, social and environmental item has been affecting the ERC. The research has recognized that the effects of the voluntary disclosure overall either the financial information or the social and the environmental information have been affecting the ERC obviously. This research has applied a controlled variable affecting the ERC refers to the opportunity to grow, capital structure and the size of the company. Choosing the variables refers to the research of Botosan (1997), Sayekti and Wondabio (2008).

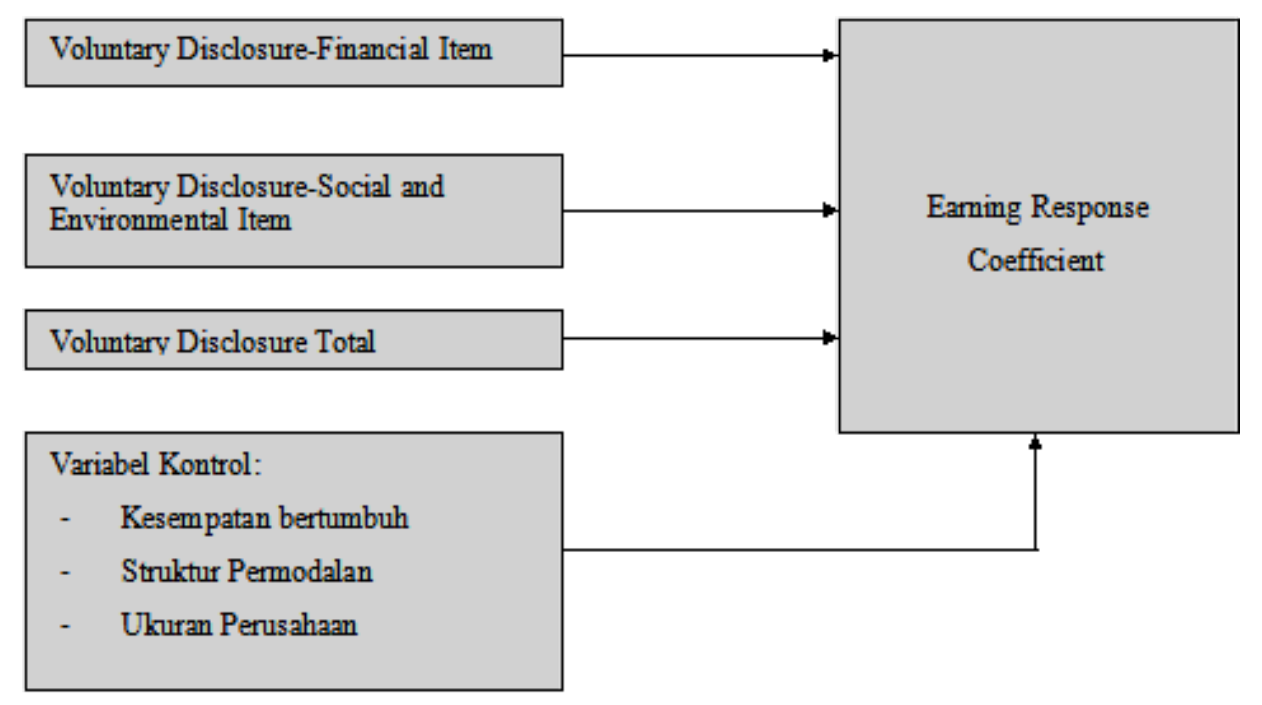

\section{Hypothesis Development}

The Voluntary Disclosure is believed to have been affecting the profit information accordingly. The additional information provided by the company has been considered as the added-value of the company for the investor to define the prospect and performance of the company instead of relying on the profit information only. Some previous researches have been in compliance with the benefit of voluntary disclosure accordingly. The research done by Utaminingtyas and Alhalik (2010) determined the same conclusion which is The CSR disclosure has affected ERC. So that, the first hypothesis to be examined in this research are as follows:

\section{$\mathrm{H}_{1}$ : Voluntary disclosure affecting the ERC.}

According to the previous voluntary disclosure which is the traditional voluntary disclosure regarding the financial information related to the economics performance of the company, and the non-traditional voluntary disclosure related to the social interaction of the company and the involvement of the environmental preservation. The researcher of this research is eager to examine each effect of the voluntary disclosure type upon the ERC. Research of Adhariani (2005) within Widyaningsih (2013) applied the evaluation references used by Botosan (1997) regarding the measurement of the voluntary disclosure. Therefore, specifically the writer has had the intention to re-evaluate the voluntary disclosure related to the financial information upon the profit information on the ERC. So that the second hypothesis to be examined are as follows:

\section{$\mathrm{H}_{2}$ : Voluntary disclosure related to the financial information has affected the ERC.}

Former researches have been analyzing the effect of non-traditional voluntary disclosure upon the ERC. The company has had a social interaction and environmental preservation involvement which is the Corporate Social Responsibility Disclosure. The 
research of Sayekti and Wondabio (2008) determined that CSR disclosure has affected negatively upon the ERC. Utaminngtyas and Ahalik (2010) within Widyanngsih (2013) indicated that a significant relationship happened between the CSR disclosure and ERC, it explains that the CSR information has affected the investor decision accordingly. The writer has been having the intention to re-examine the effect of voluntary disclosure related to the social and environment information which is getting along with the former CSR disclosure study. Then, the third hypothesis to be evaluated is as follows:

$\mathrm{H}_{3}$ : Voluntary Disclosure related to the social and environment information affecting the ERC.

\section{RESEARCH METHOD}

\section{Population and Sample}

The population and the samples of this research are all the companies registered in JII consisting of 30 syariah shares registered in BEI (Indonesia Stock Exchange) in 2014. The samples are all the population to be examined.

\section{Data types and data resources}

The research has applied a secondary data of the companies refers to their shares registered in the Jakarta Islamic Index JII), as follows;

1. The Accountancy data of the companies in 2014 covering their total asset, total debt, total equity, earning per share EPS) year of 2014 and the shares total circulated that is obtained from the scream data and reuters data.

2. The data of closing price of the shares and daily index price of varied shares (IHSG) have been obtained from yahoo finance, Bloomberg, and www.investopedia.com

3. The data of voluntary disclosure consisting of the financial information and the social and environmental information mentioned on their annual report and sustainability report had been published by the company in BEI webs (www.idx.co.id) as well as the company's webs.

\section{Measuring the Variables}

1. Dependent Variable

This research has applied dependent variable which is cumulative abnormal return (CAR). The writer applied a wide window which is 30 days before the issuance of profit announcement and 30 days after the issuance of profit announcement which is in accordance with the time intervals applied in the research of Utaminingtyas and Ahalik (2010). CAR is the calculation of the abnormal return calculated using the market-adjusted model that has been applied mostly in lots of researches refer to the research of Widiastuti (2002), Sayekti and Wondabio (2008). The calculation of the abnormal return has applied the following equations:

ARit $=$ Rit - Rmt

Description

ARit : Abnormal return of the company $i$ at $t$ day.

Rit : return of the shares of the company $i$ at $t$ day.

Rmt : return of the market on t day.

Rit $=\frac{(P t-P t-1)}{P t-1}$ 


\section{Description}

Rit : return of the shares of the compay $i$ at $t$ day.

$\mathrm{Pt} \quad$ : the price of the shares of the company $\mathrm{i}$ at $\mathrm{t}$ day

$\mathrm{Pt}-1: 1$ the price of the shares of the company $i$ at $t$ day -1 .

$R m t=\frac{(\text { IHSGt }- \text { IHSGt }-1)}{\text { IHSGt }-1}$

Description

Rmt : return market at t day

IHSGt : Index of the price of varied shares at $t$ day.

IHSGt-1: Index of the price of varied shares at $t$ day -1 .

After calculating the abnormal return, so that the equation of CAR calculation is as follows:

CARi $=\sum$ ARit

Description:

CAR : cumulative abnormal return of the company $i$ during the observation intervals which is 30 days before and 30 days after the announcement date of the profit.

ARit $\quad: t$ abnormal return of the company $i$ at $t$ day.

2. The Independent Variables

a. Unexpected Earnings (UE)

$U E i=\frac{(E P S t-E P S t-1)}{P t-1}$

Description

UEi : at the company I

EPSt : profit of each share of the company at $t$ year.

EPSt - 1: profit of each share of the company at $t$ year - 1

$\mathrm{Pt}-1$ : price of each share of the company at $\mathrm{t}$ year -1

b. Voluntary Disclosure Index

Voluntary Disclosure Index (VDI) is measured using the content analysis. The content analysis applied the dichotomy approach which is the company has given score 1 refers to the disclosure of the information component being evaluated and scor 0 for the undisclosure one. The information component to calculate VDI is the voluntary disclosure information disclosed by the companies in their yearly report and continuous reporting published. The information components to be evaluated are the financial voluntary disclosure or VDF and the social and environmental disclosure or VDSE. The applicable items had adopted the global reporting initiative (GRI) G4 version consisting of 91 items divided into 9 items of the financial information and 82 items of the social and environmental information.

The equations calculation is as follows;

VDI/VDF/VDSE $=\frac{\sum X i j}{n j}$

Description

VDI : Total of voluntary disclosure index of the company j.

Ridla Tsamrotul Fuady: The Effect of Voluntary Disclosure upon

The Earnings Response Coefficient 
VDF : financial voluntary disclosure index of the company j.

VDSE : social and environmental voluntary disclosure index of the company $\mathrm{j}$.

Xij : scoring of the disclosure of the company $\mathrm{j}$.

$\mathrm{Nj} \quad$ : scoring for each kind of disclosure.

3. Controlled Variables

a. PBV Growth opportunity

$P B V=\frac{H S i t}{\frac{N B E}{L S}}$

Description

PBV : price to book value

HSit : price of the company share at t year.

NBEit : book value of company $i$ equity at $t$ year.

LS : the quantity of the company shares circulated.

b. The capital structure (LEV)

LEVit $=$ TDit/TAit

Description

LEV : leverage ratio of company $i$ at t year.

TDit : total debt of company $i$ at $t$ year.

TAit : total assets of company $\mathrm{i}$ at $\mathrm{t}$ year.

c. The size of the company (FS)

$\mathrm{FS}=\mathrm{Ln}$ Total Asset

\section{Analysis Method}

The following models applied in this research;

1. The effect of total voluntary disclosure (VDI) upon the ERC (Model 1)

$\mathrm{CAR}=\alpha+\beta_{1} \mathrm{UE}+\beta_{2} \mathrm{VDI}+\beta_{3} \mathrm{PBV}+\beta_{4} \mathrm{LEV}+\beta_{5} \mathrm{FS}+\beta_{6} \mathrm{UE}{ }^{*} \mathrm{VDI}+\beta_{7} \mathrm{UE}{ }^{*} \mathrm{PBV}+\beta_{8}$ $U E *$ LEV $+\beta_{9} U E *$ FS

2. The effect of financial voluntary disclosure (VDF) upon the ERC (Model 2)

CAR $=\alpha+\beta_{1}$ UE $+\beta_{2}$ VDF $+\beta_{3}$ PBV $+\beta_{4}$ LEV $+\beta_{5} F S+\beta_{6}$ UE *VDF $+\beta_{7}$ UE * PBV + $\beta_{8} U E{ }^{*} L E V+\beta_{9} U E * F S$

3. The effect of social and environmental disclosure (VDSE) upon the ERC (model 3)

CAR $=\alpha+\beta_{1}$ UE $+\beta_{2}$ VDSE $+\beta_{3}$ PBV $+\beta_{4}$ LEV $+\beta_{5}$ FS $+\beta_{6}$ UE *VDSE $+\beta_{7}$ UE * PBV

$+\beta_{8} U E *$ LEV $+\beta_{9}$ UE * FS

Description

CAR : daily cumulative abnormal return of the company for 30 days before and 30 days after the announcement date of the profit.

UE $\quad$ : the unexpected earnings of the company in 2013 and 2014.

VDI : total score of the voluntary disclosure obtained by the company.

VDF : scores of the financial voluntary disclosure obtained by the company.

PBV : price to book value of the company in 2013 and 2014.

LEV : leverage ratio of the company.

FS : The size of the company.

UE*VDI : The interaction between UE variable and VDI.

UE*VDF : interaction between UE variable and VDF

UE*VDSE : interaction between UE varial and VDSE

Ridla Tsamrotul Fuady: The Effect of Voluntary Disclosure upon The Earnings Response Coefficient 
UE*PBV : interaction between UE variable and PBV.

UE*LEV : interaction betweem UE variable and LEV

UE*FS : interaction between UE variable and FS.

\section{Data Analysis Technique}

1. Normality test aims to examine whether the residual variable has had a normal distribution in the regression model by focusing the normal probability plot graph and histogram graph accordingly.

2. Multicollinearity test aims to figure out whether a high colleration among the independent variables has occurred or not in the regression model. Multicollinearity test will be done by applying the Tolerance (TOL) and Variance Inflation Factor (VIF).

3. Heterosxedasticities test has been done to examine whether a difference residual variance between one observation and the other observation has happened or not in the regression model. The analysis method has applied the scatter plot graph.

4. Autocorrelation test aims to figure out whether a correlation among a serial observation data identified based on time series or cross section has happened or not. Autocorrelation test in this research will apply the run test.

Moreover, the hypothesis test will apply the following methods:

1. Determination Coefficient $\left(R^{2}\right)$.

The determination coefficient is measuring how good such the model can describe the variation of dependent variables.

2. $t$ Statistics Test.

t statistics test has identified the effect of an independent variable individually upon the dependent variables. The effect of the independent variable upon the dependent variable is significant when the probability of its significancy (Sig) is less than 0.05 , when the probability of its significance is more than 0.05 , the independent variable is not affecting significantly upon the dependent variable $(\alpha=5 \%)$.

3. F statistics test.

F statistics test has figured out whether all independent variables mentioned on the model has affected simultaneously upon the dependent variables. Analyzing the significance of the effect of independent variables simultaneously upon the dependent variables, it should have to see the Anova table whether the significant value is less than 0.05. It explains that 0.05 indicating that the independent variables has been affecting simultaneously upon the dependent variable accordingly ( $\alpha=5 \%)$.

\section{RESULT AND DESCRIPTION}

\section{Descriptive Statistics}

A descriptive statistics test applied SPSS version 22.0 indicating on the table 1 which is the descriptive statistics has been covering the minimum value, maximum value, mean value, and deviation standard.

Table 1. Descriptive Statistics

\begin{tabular}{llrrrr}
\multicolumn{7}{c}{ Descriptive Statistics } \\
\hline & N & Minimum & Maximum & \multicolumn{1}{c}{ Mean } & Std. Deviation \\
\hline CAR & 30 & -.85 & .73 & .0639 & .29819 \\
UE & 30 & -.02 & .11 & .0143 & .02465 \\
VDF & 30 & .44 & 1.00 & .7481 & .19341 \\
VDSE & 30 & .35 & .71 & .5362 & .08348 \\
VDI & 30 & .38 & .69 & .5571 & .08244 \\
PBV & 30 & .10 & 43.14 & 4.9073 & 7.94720 \\
LEV & 30 & .14 & .95 & .4821 & .20705 \\
FS & 30 & 28.68 & 33.09 & 30.6267 & 1.04119 \\
Valid N (listwise) & 30 & & & & \\
\hline
\end{tabular}

Ridla Tsamrotul Fuady: The Effect of Voluntary Disclosure upon

The Earnings Response Coefficient 
1. According to the scattering data of CAR variables, it explains that during the regular intervals (October to December 2014) the company has gained CAR 0.0639, maximum value 0.73 and minimum value -0.85 . CAR value of the samples has varied but most of them have gained a positive return of the shares indicating that market response has been good upon the intervals of the company issued the financial report or profit announcement. The positive market response has indicated a good news provided by the company having the profit which is in compliance with the aforemention market expectation.

2. UE data scatters have indicated the good news provided by the company. The positive value of UE at average is 0.0143 refers to maximum value 0.11 and minimum value -0.02 , it explains that the company has been able to increase the profit or to minimize the losses in 2014 comparing to 2013.

3. Voluntary disclosure scorring obtained from each sample (company) has indicated that the level of the voluntary disclosure of the companies are still low and related to the data or financial information of the companies. The average of the total voluntary disclosure is $55.71 \%$ refers to maximum value $69 \%$ and minimum value $38 \%$. A big difference of voluntary disclosure between the financial information and social, environmental information has been occurred. The average of voluntary disclosure related to the social and environmental information is only $53.62 \%$ refers to the maximum value $71 \%$ and minimum value $35 \%$ indicating a big difference has occurred.

4. PBV data of the samples has varied which is the average value of 4.9. A high PBV of the company has indicated that the price of the company's shares has been increased accordingly.

5. The leverage data of the samples are varied which is the average value 0.48 refers to the maximum value 0.95 and minimum value 0.14 . All the samples (companies) have indicated the leverage value is below 1 , it can be concluded that the debt of the companies has still been able to cover the total assets of the company accordingly.

\section{Normality Test}

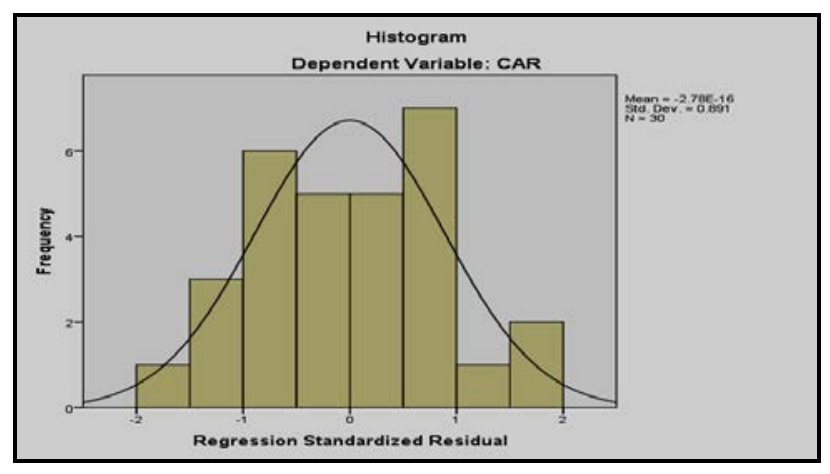

Picture 1 - The result of Normality Test

According to the aforementioned graph analysis of normal probability plot, in general the data ploting has been getting along with the diagonal line and the aforementioned histogram graph has provided a distribution patern directing to the right position which is normal distribution. Nevertheless, in order to examine the normality data more reliable, it applied a statistics test by using Kolomogrov-Smirnov. 
Table 2. The Result of Normality Test

One-Sample Kolmogorov-Smirnov Test

\begin{tabular}{|ll|r|}
\hline & & $\begin{array}{r}\text { Unstandardiz } \\
\text { ed Residual }\end{array}$ \\
\hline Normal Parameters ${ }^{\mathrm{a}, \mathrm{b}}$ & Mean & 30 \\
& Std. Deviation & .0000000 \\
Most Extreme Differences & Absolute & .25411271 \\
& Positive & .079 \\
Test Statistic & Negative & .079 \\
Asymp. Sig. (2-tailed) & & -.077 \\
\end{tabular}

a. Test distribution is Normal.

b. Calculated from data.

Source: Result of SPSS Statistic 22.0

The aforementioned test result has indicated the value of Asymp. Sig.(2-tailed) of 0.200 . It can be concluded that the data distribution is normal.

\section{Multicollinearity Test}

Table 3. The Result of Multicollinearity Test

\begin{tabular}{|c|c|c|c|c|c|c|c|c|}
\hline \multicolumn{9}{|c|}{ Coefficients $^{a}$} \\
\hline & \multirow{2}{*}{ Model } & \multicolumn{2}{|c|}{$\begin{array}{l}\text { Unstandardized } \\
\text { Coefficients }\end{array}$} & \multirow{2}{*}{$\begin{array}{c}\text { Standardized } \\
\text { Coefficients } \\
\text { Beta }\end{array}$} & \multirow{2}{*}{ t } & \multirow{2}{*}{ Sig. } & \multicolumn{2}{|c|}{$\begin{array}{l}\text { Collinearity } \\
\text { Statistics }\end{array}$} \\
\hline & & B & Std. Error & & & & $\begin{array}{l}\text { Toleranc } \\
\text { e }\end{array}$ & VIF \\
\hline \multirow[t]{11}{*}{1} & (Constant) & .494 & 1.888 & & .261 & .797 & & \\
\hline & UE & 11.656 & 196.570 & .964 & .059 & .953 & .000 & $\begin{array}{r}9098.70 \\
3\end{array}$ \\
\hline & VDF & -.159 & .364 & -.103 & -.436 & .668 & .520 & 1.921 \\
\hline & VDSE & -1.054 & .856 & -.295 & -1.231 & .233 & .505 & 1.980 \\
\hline & PBV & -.001 & .009 & -.030 & -.118 & .907 & .454 & 2.205 \\
\hline & LEV & -.013 & .326 & -.009 & -.039 & .969 & .568 & 1.762 \\
\hline & FS & .006 & .066 & .020 & .088 & .931 & .552 & 1.812 \\
\hline & UExVDI & $\begin{array}{r}-17.27 \\
3\end{array}$ & 31.960 & -.757 & -.540 & .595 & .015 & 67.603 \\
\hline & UExPBV & 1.091 & 2.185 & .177 & .499 & .623 & .231 & 4.337 \\
\hline & UExLEV & $\begin{array}{r}-51.14 \\
5\end{array}$ & 22.544 & -2.172 & -2.269 & .035 & .032 & 31.579 \\
\hline & UExFS & .602 & 6.030 & 1.527 & .100 & .922 & .000 & $\begin{array}{r}8067.85 \\
3\end{array}$ \\
\hline
\end{tabular}

a. Dependent Variable: CAR

The result of the table aformentionned has concluded that the regression model applied in this research indicated that the multicollinearity symptom has been identified refers to the VIF variable value is more than 10 . In order to reduce the multicollinearity symptom, the researcher has used the data transformation. The transformation has applied mean-centering method. Mean centering is a method to overcome the multicollinearity issue but does not change the accuracy of parameter, sample, and the interaction effect of the model using moderated variable or interaction variable 
(Echambadi, 2004) in Widyaningsih (2013). Mean-centering has to be done to reduce each independent variable data which is the average value. The result of multicollinearity test applying mean-centering idenfied on the table herebrelow:

Table 4. The Result of Multicollinearity Test after Mean-Centering.

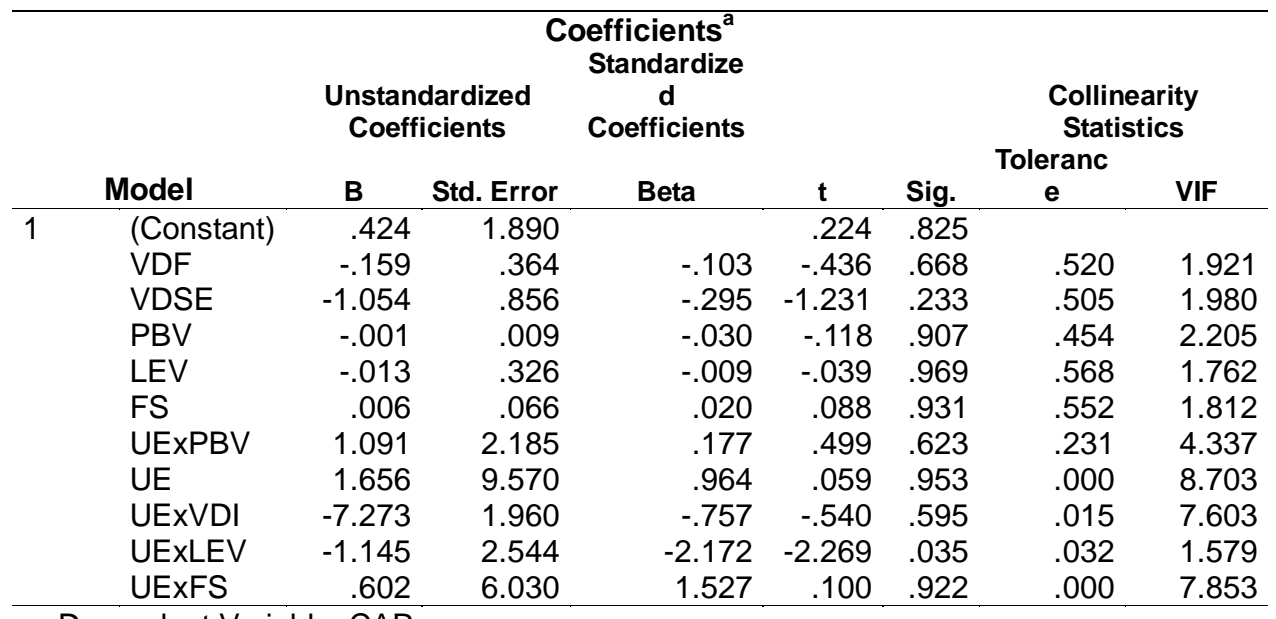

a. Dependent Variable: CAR

Based on the VIF value on the aforementioned table, it is concluded that the data transformation using mean-centering could reduce the multicollinearity symptom significantly.

\section{Heteroxedasticity Test}

Heteroxedasticity test is to examine whether a different residual variance between one observation and another observation has happened in the regression model. Heteroxedasticity test applied graph analysis and the result of this test indicated that scatterplot were scattering disorderly instead of a certain patern. It explains that there is not any heteroxedasticity problem occurred.

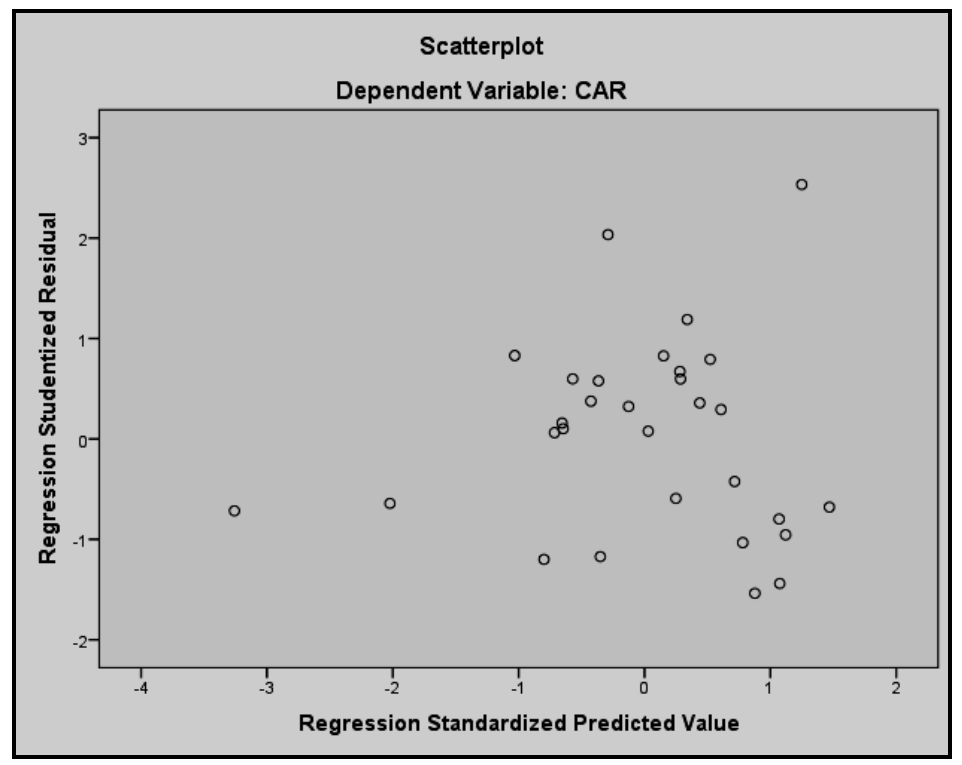

Picture 2.The Result of Heteroxedasticity Test

Ridla Tsamrotul Fuady: The Effect of Voluntary Disclosure upon The Earnings Response Coefficient 


\section{Autocorrelation Test}

Table 5. The Result of Autocorrelation Test

\begin{tabular}{|l|r|}
\multicolumn{2}{c}{ Runs Test } \\
\hline & $\begin{array}{c}\text { Unstandardize } \\
\text { d Residual }\end{array}$ \\
\hline Test Value ${ }^{\mathrm{a}}$ & .02221 \\
Cases < Test Value & 15 \\
Cases >= Test Value & 15 \\
Total Cases & 30 \\
Number of Runs & 15 \\
Z & -.186 \\
Asymp. Sig. (2-tailed) & .853 \\
\hline a. Median
\end{tabular}

Since the Asymp. Sig. value (2-tailed) has indicated 0.853 which is bigger than 0.05 , so that, it can be concluded that the autocorrelation symptom did not appear on the related model accordingly.

\section{The Model Analysis and the Hypothesis Test and the Description.}

The model analysis and the hypothesis test have applied the multiple regression analysis to figure out the determination coefficient, to examine $f$ statistics test and $t$ statistics test. The result of regression test described on the following table.

Table 6. The Result of Multiple Regression Test

\begin{tabular}{|c|c|c|c|c|c|c|}
\hline \multirow{2}{*}{$\begin{array}{l}\text { Adjusted R } \\
\text { Square } \\
\text { Koefisien dan } \\
\text { Signifikansi } \\
\text { Variable }\end{array}$} & \multicolumn{2}{|c|}{$\begin{array}{l}\text { Model I } \\
0.200\end{array}$} & \multicolumn{2}{|l|}{$\begin{array}{c}\text { Model II } \\
0.404\end{array}$} & \multicolumn{2}{|c|}{$\begin{array}{c}\text { Model III } \\
0.443\end{array}$} \\
\hline & $\begin{array}{l}\text { Unstandardized } \\
\text { Coefficients (B) }\end{array}$ & Sig. & $\begin{array}{l}\text { Unstandardized } \\
\text { Coefficients (B) }\end{array}$ & Sig. & $\begin{array}{l}\text { Unstandardize } \\
\text { d Coefficients } \\
\text { (B) }\end{array}$ & Sig. \\
\hline UE & 3.814 & .983 & 84.582 & .661 & -16.637 & .928 \\
\hline VDF & & & -.283 & .435 & & \\
\hline VDSE & & & & & -1.157 & .167 \\
\hline VDI & -1.220 & .148 & & & & \\
\hline PBV & -.001 & .877 & -.001 & .895 & -.002 & .792 \\
\hline LEV & -.014 & .965 & .051 & .878 & -.012 & .969 \\
\hline FS & .003 & .965 & .002 & .981 & -.009 & .869 \\
\hline UExVDI & -16.166 & .590 & & & & \\
\hline UExVDF & & & -43.224 & .091 & & \\
\hline UExVDSE & & & & & -14.710 & .638 \\
\hline UEXPBV & 1.154 & .580 & .875 & .696 & 1.351 & .519 \\
\hline UExLEV & -51.054 & .031 & -58.988 & .014 & -51.456 & .030 \\
\hline UExFS & .837 & .880 & -1.205 & .841 & 1.484 & .792 \\
\hline Uji Statistik F & $\begin{array}{r}F \\
1.804\end{array}$ & $\begin{array}{r}\text { Sig. } \\
0.130\end{array}$ & $\begin{array}{r}F \\
1.509\end{array}$ & $\begin{array}{r}\text { Sig. } \\
0.112\end{array}$ & $\begin{array}{r}F \\
1.767\end{array}$ & $\begin{array}{l}\text { Sig. } \\
0.139\end{array}$ \\
\hline Kesimpulan & & $\mathrm{f}_{1}$ ditolak & & ${ }_{2}$ ditolak & & ${ }_{3}$ ditolak \\
\hline
\end{tabular}

Based on the aforementioned table, the value of determination coefficient can be recognized on the Adjusted $R$ Square figures at each model which is; $0.200 ; 0.404$ and 0.443 ; it explains that $20 \%$; $40.4 \%$; and $44.3 \%$ of CAR variation can be described by the variation of the independent variables which is the unexpected earnings and voluntary disclosure scores, as well as controlled variables refers to price to book value, leverage and the size of the company. And the remaining which is $80 \% ; 59.6 \%$ and $55.7 \%$ has been described by unapplied variable in this research. Based on the result of Anova test or $f$ test of each model, it has obtained f-calculated 1.804; 1.509 amd 1.767 with the probabilities of $0.130 ; 0.112$ and 0.139 .

Ridla Tsamrotul Fuady: The Effect of Voluntary Disclosure upon

The Earnings Response Coefficient 
The result of the hypothesis test is in compliance with the aforementioned table and can be concluded as follows;

1. $H_{1}$ : Voluntary disclosure has affected the ERC

Based on the result of regression test, it has concluded that the voluntary disclosure has not affected the ERC completely. The significant value of UExVDI is bigger than $0.05(5 \%)$ so that, $\mathrm{H}_{1}$ is rejected.

2. $\mathrm{H}_{2}$ : Voluntary Disclosure related to the financial information has affected the ERC.

Based on the result of the regression test, it concluded that voluntary disclosure related to the financial information has not affected the ERC significantly. The significant value of UEXVDF is bigger than $0.05(5 \%)$ so that, $\mathrm{H}_{2}$ is rejected.

3. $\mathrm{H}_{3}$ : Voluntary Disclosure related to the social and environmental information has affected the ERC.

Based on the result of regression test, it concluded that voluntary disclosure related to social and environmental information has not affected the ERC significantly. The significant value of UExVDSE is bigger than $0.05(5 \%)$, so that $\mathrm{H}_{3}$ is rejected.

So that, this research can not prove the former hypothesis accordingly refers to the voluntary disclosure affecting the ERC. The test of the three models can not identify the significant effect either the voluntary disclosure related to financial information or the social and environmental information accordingly.

The possible descriptions about the result of the research are as the following;

1. Voluntary disclosure being examined in this research has not provided a sufficient description about the information needed by the investor to evaluate the future prospect of the company accordingly. In compliance with the description of Widyaningsih (2013) who declared that the voluntary disclosure examined in the research has not provided a sufficient information related to the expected future earnings so that the investor will be able to use only the profit information to determine the expected future earnings considerately.

2. Voluntary disclosure evaluation related either to the financial information or the social and environmental information did not describe sufficiently the scope of voluntary disclosure done by each company.

3. This research is in compliance with the research done by Widyaningsih (2013) that has examined the effect of voluntary disclosure upon the earnings response coefficient refers to 120 manufacturing companies registered in BEl. The research cannot describe the effects of the voluntary disclosure upon the earnings response coefficient absolutely.

\section{The Analysis Level of Voluntary Disclosure of the company}

The information disclosure offered in the yearly report including the financial report and continuous reporting can be categorized into two kinds of information which is the financial information and the social and environmental information accordingly. Based on the content of the analysis upon the yearly report of the samples, it has obtained the score of voluntary disclosure of the sample as the following tables:

Table 7. The level of Voluntary Disclosure related to the Financial Information

\begin{tabular}{cccc}
\hline $\begin{array}{c}\text { Jenis Informasi yang } \\
\text { Diungkapkan }\end{array}$ & $\begin{array}{c}\text { Average } \\
\text { Disclosure }\end{array}$ & Min. Score & Max. Score \\
\hline Economic & $74.81 \%$ & 4 & 9 \\
Performance & & & \\
\hline
\end{tabular}


Based on the table 7 , it indicated that the average of the disclosure about the economics performance of the company is quite big which is $74.81 \%$ and the minimum score of 4 and maximum score of 9 against the total disclosure of the economic performance which is 9 items adopted from $\mathrm{G} 4$.

Table 8. Level of the voluntary disclosure related to social and environmental information.

\begin{tabular}{llccc}
\hline No & \multicolumn{1}{c}{$\begin{array}{c}\text { Jenis Informasi yang } \\
\text { Diungkapkan }\end{array}$} & $\begin{array}{c}\text { Average } \\
\text { Disclosure }\end{array}$ & Min. Score & Max. Score \\
\hline 1. & Environmental & $53.13 \%$ & $26.47 \%$ & $70.59 \%$ \\
2. & Social Labor Practices and & $76.7 \%$ & $31.25 \%$ & $100 \%$ \\
& Decent Work & $52.78 \%$ & & \\
3. & Social: Human Rights & $16.36 \%$ & $9.33 \%$ & $66.67 \%$ \\
4. & Social: Society & $60.74 \%$ & $11.11 \%$ & $36.36 \%$ \\
5. & Social: Product & & & \\
& Responsibility & & \\
\hline
\end{tabular}

Based on table 8 about the disclosure of social and environmental information, most of the information disclosures are social labor practices and decent work as well as product responsibility. But, less information disclosures are related to society, human rights and environment. Level the disclosure related to the society, human rights and environment of the companies registered in JII has not yet concerned about providing the related information. Most of the companies actually have disclosed the social and environmental information separately which is the report of social responsibility itself. Moreover, the disclosed information is varied. The information provided has been focusing on the social support activities and community development surroundings the company only, the information about the company involvement to the environmental preservation has been reported a little.

\section{CONCLUSION AND LIMITATION}

\section{Conclusion}

According to the test result upon the 30 companies listed on $\mathrm{JII}$, it can not identify empirically the voluntary disclosure affecting the earning response coefficient (ERC). The similar conclusion has been obtained accordingly about each voluntary disclosure which is the voluntary disclosure related to the financial information and the information about social and environment.

\section{Limitation and Suggestion}

The limitation of this research and the suggestion required to improve the following research, as follows:

a. CAR intervals of this research applied 30 days time intervals before and 30 days after the issuance date of the profit report. The future research can use longer time intervals and apply some calculation intervals to examine the sensitivity of test result.

b. This research used only three controlled variables which is leverage, price to book value and the size of a company. Further research can use other controlled variables that have been affecting the ERC refers to beta of the profit persistence.

c. According to the content analysis about the voluntary disclosure coverage in the yearly report, subjectivity of the research has been figured out. Further research is expected to perform a repetitive content analysis done by some researchers focusing to one object only to reduce a subjective matter. 


\section{REFERENCES}

Wulandari, Kadek Trisna. 2014. Pengaruh Pengungkapan Corporate Social Responsibility terhadap Earnings Response Coefficient. Universitas Udayana Bali.

Winisaputri, Refita. 2014. Pengaruh Corporate Sosial Responsibility (CSR), Firm Size, Leverage, Growth Opportunities terhadap Earning Response Coefficient (ERC) (Studi Empiris pada Perusahaan Indeks LQ45 di BEI). Universitas Bung Hatta.

Widyaningsih, Andriyani. 2013. Analisis Pengaruh Pengungkapan Sukarela terhadap EC (Studi Empiris pada Perusahaan Manufaktur yang Terdaftar di BEI Tahun 2011). Working Paper. Universitas Indonesia

Iswardani, Galuh. 2012. Pengaruh Tingkat Keluasan Pengungkapan Sukarela dalam Laporan Tahunan terhadap ERC: Studi Empiris pada Perusahaan Manufaktur yang Tercatat di BEI Periode 2009-2010. Working Paper. Universitas Indonesia.

Lako, Andreas. 2011. Deskontruksi Corporate Social Responsibility (CSR) \& Reformasi Paradigma Bisnis dan Akuntansi. Jakarta: Erlangga.

Jayanti, Erny Dwi. 2011. Pengaruh Pengungkapan Tanggung Jawab Sosial terhadap Earning Response Coefficient (ERC) (Studi pada Sektor Pertambangan yang Terdaftar di BEI Tahun 2010-2011).

Sukaharsono, Eko Ganis. 2010. Metamorfosis Akuntansi Sosial dan Lingkungan: Mengkonstruksi Akuntansi Sustanabilitas Berdimensi Spiritualitas. Working Paper. Universitas Brawijaya Malang.

Fauzi, Hasan. 2008. Corporate Social and Environmental Performance: A Comparative Study of Indonesian Companies and Multinational Companies (MNCs) Operating in Indonesia. Journal of Knowledge Globalization, Vol. 1, No 1. Universitas Sebelas Maret.

Undang-Undang Perseroan Terbatas Pasal 24 No. 40 Tahun 2007

Solihin, Ismail. 2009. Corporate Responsibility: From Charity to Sustainability. Jakarta: Salemba Empat.

Global Reporting Initiative. 2013. Sustainability Reporting Guidelines. G4.

European Bank for Rescontruction and Development. EBRD Environmental and Social Risk Categorisation List-2011

Sayekti, Yosefa. 2007. Pengaruh CSR Disclosure terhadap Earning Response Coefficient (Suatu Studi Empiris pada Perusahaan yang Terdaftar di Bursa Efek Jakarta). Simposium Nasional Akuntansi $X$.

Fitriana, Erlyn Nur. 2008. Pengaruh Pengungkapan Corporate Social Responsibility dalam Laporan Tahunan terhadap Koefisien Respon Laba Akuntansi (Studi Empiris pada Perusahaan Manufaktur yang List di BEI 2007- 2008). Universitas Dipenogoro.

Pradipta, Dyah Hayu. 2013. Pengaruh Luas Pengungkapan Tanggung Jawab Sosial dan Lingkungan Perusahaan terhadap Earning Response Coefficient (ERC), dengan Ukuran Perusahaan dan Leverage Sebagai Variabel Kontrol. Universitas Atma Jaya. 
Daud, Rulfah M. 2008. Pengaruh Corporate Social Responsibility Disclosure, Timeliness, dan Debt To Equity Ratio terhadap Earning Response Coefficient (Studi Empiris pada Perusahaan Manufaktur yang Terdaftar di Bursa Efek Indonesia). Universitas Syiah Kuala.

Andriani, Desi. 2005. Tingkat Keluasan Pengungkapan Sukarela dalam Laporan Tahunan dan Hubungannya dengan Current ERC. Universitas Indonesia.

Widiastuti, Harjanti. 2002. Pengaruh Luas Ungkapan Sukarela dalam Laporan Tahunan terhadap Earning Response Coefficient (ERC). Simposium Nasional Akuntansi 5 Semarang. FE UI. 
The Accounting Journal of BINANIAGA Vol. 02, No. 01, 2017

PISSN: $2527-4309$

EISSN: $2580-1481$

This page intentionally be emptied.

Ridla Tsamrotul Fuady: The Effect of Voluntary Disclosure upon The Earnings Response Coefficient

Page : 38 